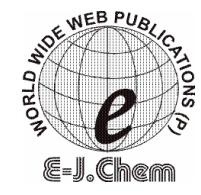

http://www.e-journals.net
ISSN: 0973-4945; CODEN ECJHAO

E-Journal of Chemistry

Vol. 5, No. 1, pp. 81-85, January 2008

\title{
Production of Cellulosic Polymers from Agricultural Wastes
}

\author{
A.U. ISRAEL, I.B. OBOT*, S. A. UMOREN, \\ V. MKPENIE and J.E. ASUQUO \\ Department of Chemistry,Faculty of Science, University of Uyo, \\ P.M.B. 1017, Uyo, Nigeria. \\ proffoime@yahoo.com
}

Received 12 May 2007; Accepted 10 July 2007

\begin{abstract}
Cellulosic polymers namely cellulose, di-and triacetate were produced from fourteen agricultural wastes; Branch and fiber after oil extraction from oil palm (Elais guineensis), raffia, piassava, bamboo pulp, bamboo bark from raphia palm (Raphia hookeri), stem and cob of maize plant (Zea mays), fruit fiber from coconut fruit (Cocos nucifera), sawdusts from cotton tree (Cossypium hirsutum), pear wood (Manilkara obovata), stem of Southern gamba green (Andropogon tectorus), sugarcane baggase (Saccharium officinarum) and plantain stem (Musa paradisiaca). They were subjected to soda pulping and hypochlorite bleaching system. Results obtained show that pulp yield from these materials were: 70.00, 39.59, 55.40, 86.00, 84.60, 80.00, $40.84,81.67,35.70,69.11,4.54,47.19,31.70$ and $52.44 \%$ respectively. The pulps were acetylated with acetic anhydride in ethanoic acid catalyzed by conc. $\mathrm{H}_{2} \mathrm{SO}_{4}$ to obtain cellulose derivatives (Cellulose diacetate and triacetate). The cellulose diacetate yields were 41.20, 17.85, 23.13, 20.80, 20.23, 20.00, $39.00,44.00,18.80,20.75,20.03,41.20,44.00$, and $39.00 \%$ respectively while the results obtained as average of four determinations for cellulose triacetate yields were: 52.00, 51.00, 43.10, 46.60, 49.00, 35.00, 40.60, 54.00, 57.50, $62.52,35.70 .52 .00,53.00$ and $38.70 \%$ respectively for all the agricultural wastes utilized. The presence of these cellulose derivatives was confirmed by a solubility test in acetone and chloroform.
\end{abstract}

Keywords: Cellulose polymers, Proximate composition, Pulping, Acetylation.

\section{Introduction}

Many agricultural by-products from agricultural activities and agro-based processing litter the environments and constitute waste problems. This research is aimed at converting some of these unwanted agricultural waste or by-products to commercially useful products such as pulp and cellulose acetate. This work has the potential of providing new market and applications for low value and utilized agricultural wastes by converting into cellulose acetate. The principle 
behind the research is that most agricultural by-products are composed of cellulose in the plant cell walls. Cellulose $\left(\mathrm{C}_{6} \mathrm{H}_{10} \mathrm{O}_{5}\right)_{n}$ is a large chain polymeric polysaccharide carbohydrate of betaglucose. The principal functional groups in pure cellulose are hydroxy $(-\mathrm{OH})$ making cellulose a polyol with primary and secondary alcohol functional groups $\left(-\mathrm{CH}_{2} \mathrm{OH},-\mathrm{CHOH}\right)$.

The multiple hydroxy groups of cellulose in cellulosic materials (agro-waste) can be partially or wholly modified by reacting with various chemicals to produce a wide range of end products referred to as 'cellulose derivatives'. These derivatives such as cellulose nitrates, acetates, xanthates, ethers, rayon and cellophanes have far reaching industrial applications. Cellulose nitrate has the largest industrial use as lacquer coating for decorative and protective purposes. It is also useful in the photographic industry, in explosives and propellants ${ }^{1-4}$.

Among all cellulose derivatives, cellulose acetate as by far been recognized as the most important organic ester of cellulose owing to its extensive industrial and commercial importance. It has many uses such as in the production of plastics films, lacquers, photographic films, thermoplastic moulding, transparent sheeting, camera accessories, magnetic tapes, combs, telephone, and electrical parts ${ }^{5-7}$.

The production of cellulose acetate from agro-waste such as jute stick, cotton linters, woodchips, rice straw, wheat hull and corn fiber have been reported in literature ${ }^{8,1,7}$.

In Nigeria, enormous volumes of agricultural wastes that contain cellulosic fibers are generated annually. Many of these agro-wastes are allowed to rot away utilized. For example, tonnes of maize stem, cobs from Zea mays, plantain stem, raffia from Raphia hookeri are allowed to rot away yearly and eventually polluting the environment. These agricultural wastes can be gainfully utilized in the production of pulp for papermaking and conversion to cellulose derivatives for manufacture of plastics, photographic films etc. This will not only encourage local farmers as new market is developed for materials but will also boost the Nigerian economy. Also the problem of environmental pollution arising from the decay of these materials will be minimized. Recently, our research group has reported on the conversion of some agricultural wastes to cellulose derivatives ${ }^{7}$. The present work is another trial aimed at practically exploiting these biodegradable agricultural wastes materials as a potential alternative for the production of pulps and subsequent conversion to cellulose derivatives.

\section{Experimental}

Agricultural wastes used were branch, fiber after oil extraction of Elais guineensis (oil palm tree), fiber of Cocos nucifera, raffia, bamboo pulp and bark from Raphia hookeri, maize cob and stem from Zea mays, sawdust from Manilkara obovate (pear wood), sawdust from Gosspium hirsutum (cotton tree), stem from Andropogon tectoris (Southern gamba grass) and stem of Musa paradisiaca (plantain). They were obtained from Uyo area of Akwa Ibom State, Nigeria and authenticated by a botanist in the Department of Botany, University of Uyo, Nigeria. Chemical/ reagents used were Analar grade and were therefore used without further purification. The samples were allowed to dry and thereafter were sliced into small pieces and beaten to reduce the filaments for further analysis.

Proximate compositions, moisture content, solubility in $1 \% \mathrm{NaOH}$, cellulose content were determined using standard methods of the Association of Official Analytical $\mathrm{Chemist}^{10}$. The presence of lignin and rosin in the samples were detected using phloroglucinol solution and Hierberman-starch method respectively ${ }^{3}$.

The pulping process employed was the soda pulping method. 10.0g of each of the sample were boiled with $200.0 \mathrm{~mL}$ of $18 \% \mathrm{NaOH}$ solution for one hour. The resulting mixture was 
filtered off and washed with distilled water to free the fibers (defibiring). The samples were collectively bleached using hypochlorite in alkaline medium. The bleached samples were dried at $80 \pm 5{ }^{\circ} \mathrm{C}$ in the oven for $8 \mathrm{~h}$ to give cellulose pulp. Moisture content of the wet pulp and pulp yield were estimated.

\section{Preparation of Cellulose Acetates}

$2.0 \mathrm{~g}$ of each of the dried bleached pulp was dispersed in $35 \mathrm{~mL}$ of glacial acetic acid. The solution was kept in water bath between $50-55{ }^{\circ} \mathrm{C}$ for one hour with frequent stirring. An acetylating mixture of $0.4 \mathrm{~mL}$ conc. $\mathrm{H}_{2} \mathrm{SO}_{4}$ and $10 \mathrm{~mL}$ of acetic anhydride was gradually added to the glacial acetic acid-pulp mixture, keeping the temperature between $60 \pm 5^{\circ} \mathrm{C}$. The resulting mixture was kept in water bath for an hour at $50-55{ }^{\circ} \mathrm{C}$ with occasional stirring until a clear solution was obtained. The clear solution was divided into two portions: to one-half were precipitated triacetate and other portion diacetate. The precipitates was filtered and washed thoroughly until it was neutral to litmus. The precipitates were dried and subjected to solubility test in chloroform and acetone to confirm their presence. The solubility properties of cellulose diacetate and triacetate in chloroform and acetone as well as their yields were determined.

\section{Results and Discussion}

The results of the proximate composition, cellulose content, pulp yields, moisture contents of the pulp and cellulose derivatives yield of the agricultural wastes under investigation are presented in Table $1 \& 2$. From the table, the moisture content of the air-dried samples in $\%$ were 47.50, 28.90,14.20, 42.00, 36.00, $10.7046 .00,45.00,30.20,41.00,57.70,39.78,16.88$ and $50.00 \%$ respectively for branch and fiber after oil extraction from oil palm (Elais guineensis), raffia, piassava, bamboo pulp, bamboo bark from raphia palm (Raphia hookeri), stem and cob of maize plant (Zea mays), fruit fiber from coconut fruit (Cocos nucifera), sawdusts from cotton tree (Cossypium hirsutum), pear wood (Manilkara obovata), stem of Southern gamba green (Andropogon tectorus), sugarcane baggase (Saccharium officinarum) and plantain stem (Musa paradisiaca). The lower the moisture content of the agricultural waste, the higher the fiber content of the sample. The low moisture content of raffia and bamboo bark from Raphia hookeri show the high fiber contents of these samples ${ }^{7}$.

Table 1. Proximate Composition and Acetate Yield of Some Agricultural Waste Materials.

\begin{tabular}{cccccccccc}
\hline & \multicolumn{2}{c}{$\begin{array}{c}\text { Elais } \\
\text { guineensis }\end{array}$} & \multicolumn{4}{c}{ Raffia } & \multicolumn{2}{c}{ hookeri } & \multicolumn{2}{c}{ Zea mays } \\
\cline { 2 - 10 } & Branch & $\begin{array}{c}\text { Fruit } \\
\text { fiber }\end{array}$ & Raphia Piassava & $\begin{array}{c}\text { pulp } \\
\text { Bambo }\end{array}$ & $\begin{array}{c}\text { Bambo } \\
\text { bark }\end{array}$ & Stem & Cob \\
\hline $\begin{array}{c}\text { Moisture content, \% } \\
\text { Solubility in hot } \\
\text { water, \% }\end{array}$ & 47.50 & 28.90 & 14.20 & 42.00 & 36.00 & 10.70 & 46.00 & 45.00 \\
$\begin{array}{c}\text { Solubility in 1\% } \\
\text { NaOH, \% }\end{array}$ & 15.50 & 10.00 & 6.85 & 10.75 & 10.00 & 12.50 & 17.50 & 15.00 \\
$\begin{array}{c}\text { Cellulose content, \% } \\
\text { Pulp yield, \% }\end{array}$ & 61.10 & n.d & 39.00 & 63.00 & 58.00 & 49.50 & 60.00 & 60.00 \\
$\begin{array}{c}\text { Moisture content of } \\
\text { wet pulp, \% }\end{array}$ & 70.00 & 68.70 & 71.50 & 80.00 & 76.50 & 75.50 & 53.50 & 53.50 \\
$\begin{array}{c}\text { Cellulose diacetate, \% } \\
\text { Cellulose }\end{array}$ & 41.20 & 17.85 & 23.13 & 20.80 & 20.23 & 20.00 & 39.00 & 44.00 \\
$\quad$ Triacetate, \% & 52.00 & 51.00 & 43.10 & 46.60 & 49.00 & 35.00 & 40.60 & 40.60 \\
\hline
\end{tabular}


Table 2. Proximate Composition and Acetate Yield of Some Agricultural Waste Materials.

\begin{tabular}{lcccccc}
\hline \multicolumn{1}{c}{ Assay } & $\begin{array}{l}\text { Cocos } \\
\text { nucifera } \\
\text { fruit } \\
\text { fiber }\end{array}$ & $\begin{array}{l}\text { Manilkara } \\
\text { Obovata } \\
\text { (Sawdust) }\end{array}$ & $\begin{array}{l}\text { Gosspium } \\
\text { hirsutum }\end{array}$ & $\begin{array}{l}\text { Andropogon } \\
\text { Tectorus } \\
\text { (stem) }\end{array}$ & $\begin{array}{l}\text { Saccharium } \\
\text { officinarium }\end{array}$ & $\begin{array}{l}\text { Musa } \\
\text { paradi } \\
\text { siaca }\end{array}$ \\
\hline $\begin{array}{l}\text { Moisture content, \% } \\
\text { Solubility in hot }\end{array}$ & 30.20 & 41.00 & 57.70 & 39.78 & 16.88 & 50.00 \\
$\begin{array}{l}\text { water, \% } \\
\text { Solubility in 1\% }\end{array}$ & 16.00 & 8.00 & 12.50 & 11.00 & 15.50 & 10.00 \\
NaOH, \% & 16.50 & 26.00 & 42.70 & 25.00 & 55.00 & 25.00 \\
Cellulose content, \% & n.d & n.d & n.d & 65.10 & 43.25 & 37.50 \\
$\begin{array}{l}\text { Pulp yield, \% } \\
\text { Moisture content of }\end{array}$ & 35.70 & 69.11 & 4.54 & 47.19 & 31.70 & 52.44 \\
wet pulp, \% & 64.30 & 30.89 & 64.71 & 70.00 & 66.00 & 49.00 \\
$\begin{array}{l}\text { Cellulose diacetate \% } \\
\text { Cellulose Triacetate \% }\end{array}$ & 18.80 & 20.75 & 20.03 & 41.20 & 44.00 & 39.00 \\
\hline
\end{tabular}

n.d $=$ not detected

Solubility test in hot water for all the samples revealed that maize stem had the extractable material in hot water $(17.50 \%)$ while sawdust of pear wood (Manilkera obovata) had the least $(8.0 \%)$. It is not surprising that Manilkera obovata-a hardwood contains least extractable than the maize stem, which has more cellular structure containing soft fiber with an embedded non-cellulosic materials ${ }^{10}$. Also the solubility tests of these agricultural wastes in $1 \% \mathrm{NaOH}$ were in all cases greater than solubility in hot water. Generally the relatively high solubility of these samples in $1 \% \mathrm{NaOH}$ may be attributed to the soda pulping process which might have resulted in heavy loss in cellulose materials since $\mathrm{NaOH}$ usually degrades both cellulose and hemicellulose as well as lignin especially if used in excess.

Results of the pulp yield showed the woody samples of piassava, bamboo pulp, bamboo bark, maize cob, sawdust of pear wood, branch of oil palm tree (Elais guineensis) were $86.00,84.60,80.00,81.67,69.11$ and $70.00 \%$ respectively while the non-woody samples of Musa paradisiaca, fruit fiber of oil palm after extraction, fruit fiber of coconut fruit, sugarcane baggase, southern gamba grass and sawdust of cotton (Gosspium hirsutum) were $52.44,39.59,35.70,31.70,47.19$, and 4.54 respectively. The woody samples showed significant pulp yield because they contain more fibers ${ }^{11,12}$.

Cellulose content of the agricultural waste increase in the order: Musa paradisiaca, Saccharium officinarium, (raffia, bamboo bark, pulp) all from Raphia hookeri, maize stem/cobs, piassava, southern gamba grass (Andropogon tectorus), and branch of oil palm tree (Elais guineensis). The high cellulose content of Elais guineensis and southern gamba grass (Andropogon tectorus) may be due to increase fiber content of the material which hindered great loss of cellulose during processing such as washing and defibering.

Acetylation of the pulp with acetic anhydride in ethanoic acid catalyzed by conc. $\mathrm{H}_{2} \mathrm{SO}_{4}$ yielded cellulose acetate derivatives- diacetate and triacetate. The diacetate yield for branch of oil palm tree (Elais guineensis), raffia, piassava, bamboo pulp and bark, stem and cob of Zea mays, fiber of coconut fruit, sawdust of pear wood, sawdust of cotton tree, stem of gamba grass, sugarcane baggase and Musa paradisiaca were 42.10, 17.85, 23.13, 20.80, $20.23,20.00,39.00,44.00,18.80,20.75,20.03,41.20,44.00$, and $39.00 \%$ respectively. Also the triacetate yield were $52.00,51.00,43.10,46.60,49.00,35.00,40.60 .54 .00,57.00,62.52$, 
$35.70,52.00$ and $38.70 \%$ respectively. The triacetate were higher in value in value than the corresponding diacetates. This difference is due to the partial acetylation of cellulose in diacetate and the full acetylation of cellulose in the triacetates respectively ${ }^{13}$.

The cellulose acetate derivatives were confirmed by subjecting them to solubility test in chloroform and acetone. The diacetates were soluble in acetone while the triacetates were completely soluble in chloroform. Both acetates are insoluble in ethanol and formaldehyde. As a result of their solubility in selected solvents, they can be easily isolated from one another.

\section{Conclusions}

It has been shown that these materials which were regarded as agricultural wastes and allowed to rot away thereby constituting a nuisance to the environment contain cellulose. When subjected to soda pulping yielded substantial cellulose pulp used in papermaking. These pulps when acetylated yield cellulose acetate derivatives - cellulose diacetate and triacetate that can be used to produce plastics, photographic film, magnetic tapes, protective coatings, and electrical parts.

\section{References}

1. Tanghe L J, Genung L B and Mench J W, "In Advances in Carbohydrate Chemistry", Academic Press, 1963, 193.

2. Rowel M R, Modified Cellulosics, Academic Press Inc., New York, 1987, 23-34.

3. Browning B L, The Chemistry of Wood $4^{\text {th }}$ Ed.. Interscience Publishers Inc., New York, 1990, 56-63.

4. Klem D, Bertram P and Heinze T, Comprehensive Cellulose Chemistry: Fundamental and Analytical Methods, John Wiley and Sons Inc., U.S.A., 1998, 1, 105-107

5. Calihan C D, Cellulose Derivatives, Polymers with a Future in Cellulose Technology Research, A. F. Turball Ed.. American Chemical Society symposium series No. 10 Washington DC. U.S.A., 1987

6. Amin M N and Shahjehan M D, 1999. J. Sci. Ind. Research, 1999, 42(6), 377-379.

7. Umoren S A., Umoudoh A J and Akpabio, UD, 2004, Bulletin of Pure and Applied Sciences, 2004, 23, 9 -13.

8. Li J, Xie W, Cheng H N, Nickol R G and Wang P G, Macromolecules, 1999,32, 2789.

9. A O A C, Association of Official Analytical Chemist: Official Method of Analysis $12^{\text {th }}$ Ed. Benjamin Franklin Station, Washington DC. William Horwitz, 1975.

10. Udonne A D, Preparation of Cellulose Derivatives from some Agricultural Wastes: B.Sc Thesis. University of Uyo, Nigeria, 2006, 41-48.

11. John W S, Hearle S, Calvin R and Woodings C R, "Fibers related to Cellulose" In Regenerated Cellulose Fibers Woodhead Publishing Ltd., USA., 2001, 352.

12. Casey J P, Pulp and Paper Chemistry and Chemical Technology, John Wiley and Sons, U.S.A., 2000, 3(1), 150-152.

13. Browning B L, The chemistry of wood $6^{\text {th }}$ Ed., Interscience Publishers Inc., New York, 1997, 56-63. 


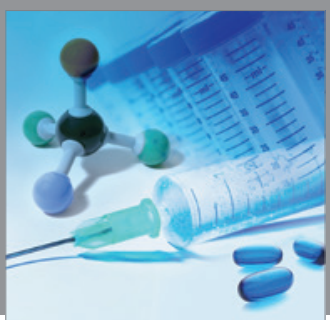

International Journal of

Medicinal Chemistry

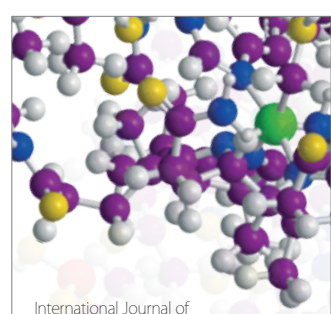

Carbohydrate Chemistry

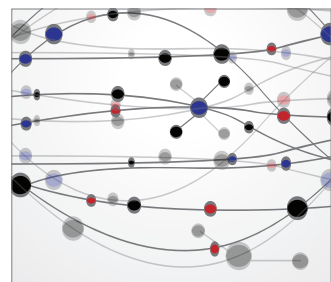

The Scientific World Journal
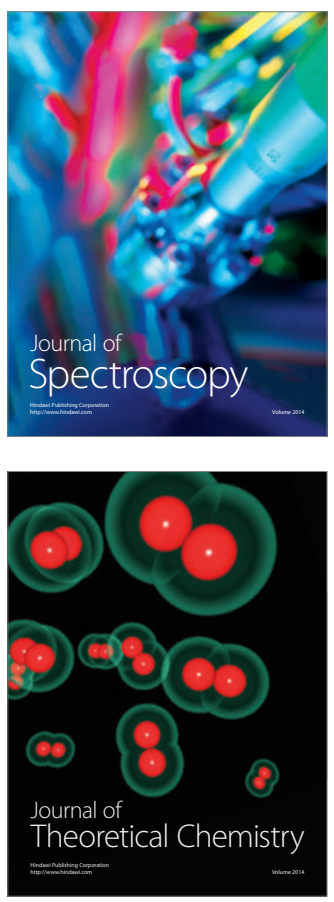
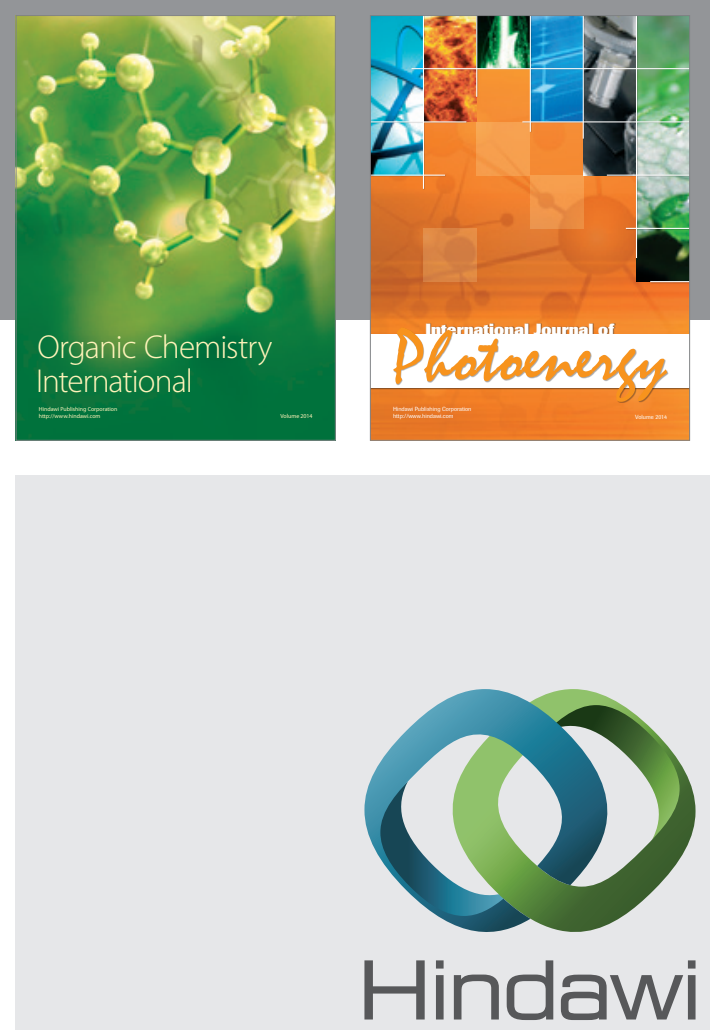

Submit your manuscripts at

http://www.hindawi.com
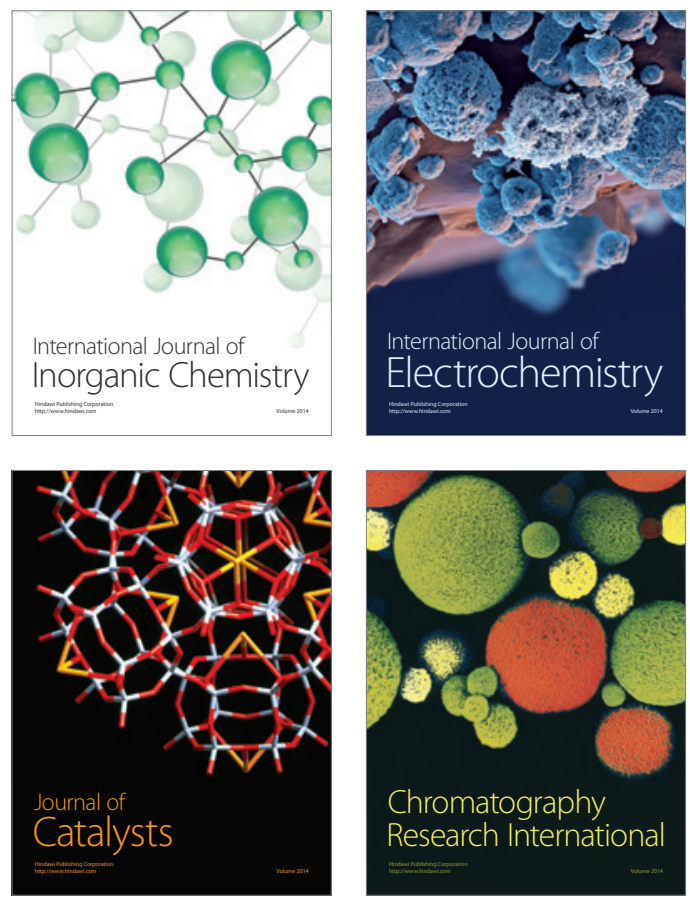
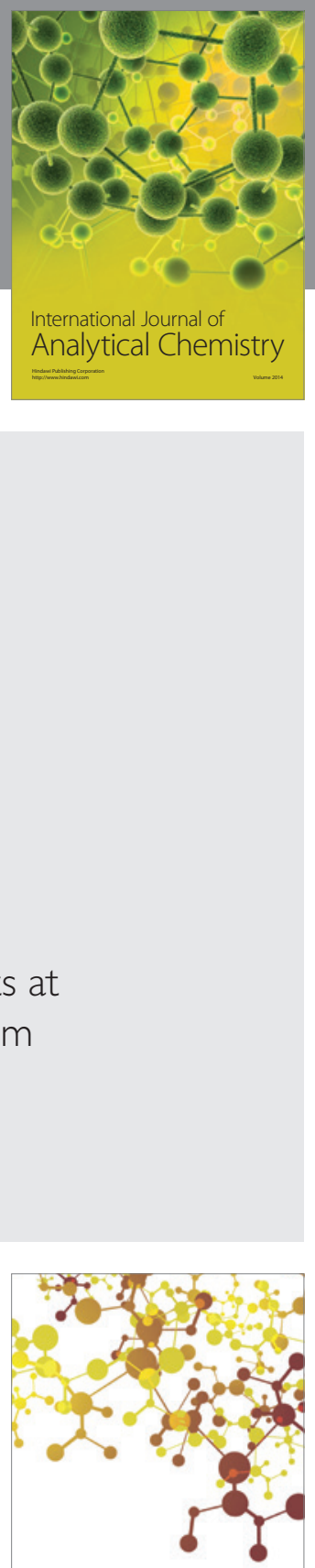

Journal of

Applied Chemistry
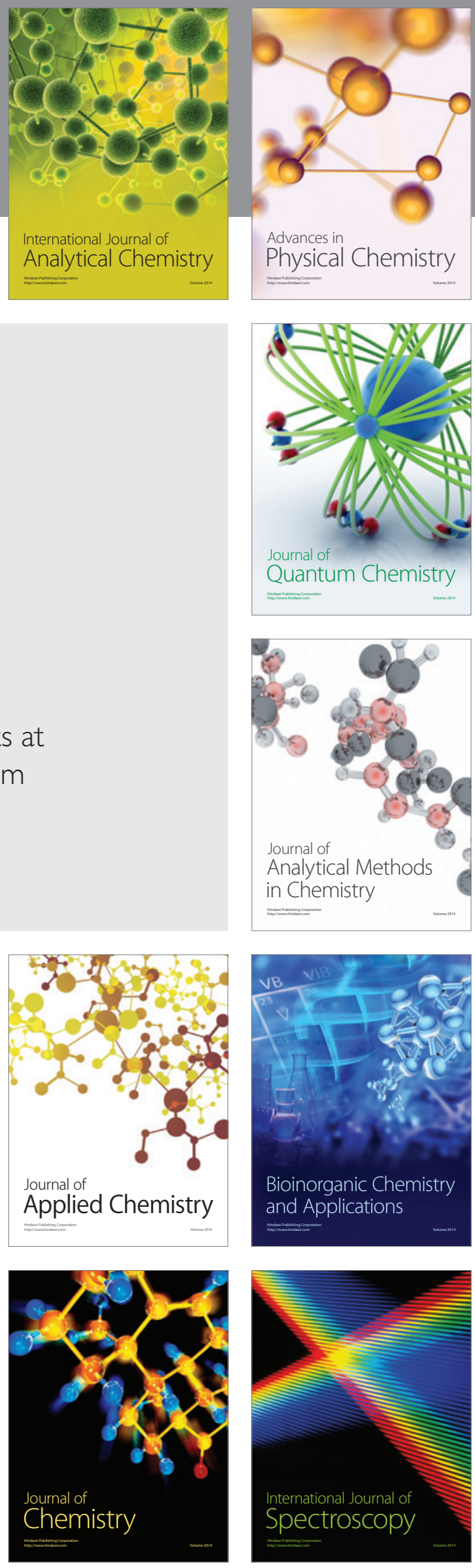